\title{
Spontaneous Pneumomediastinum in COVID-19 Patient: A Case Report
}

\section{COVID-19 Bağlı Gelişen Spontan Pnömomediastinum: Olgu Sunumu}

\author{
Dilek Ergün, @Recai Ergün, @Nurettin Andaç Atalay, @Fikret Kanat, @Baykal Tülek, @Burcu Yormaz
}

University of Selcuk, Faculty of Medicine Department of Chest Diseases, Konya, Turkey

\begin{abstract}
Spontaneous pneumomediastinum has been reported as a rare complication in COVID-19 pneumonia. Symptoms in pneumomediastinum are usually nonspecific. A 36-yearold male patient was admitted to our clinic with shortness of breath, cough, and left flank pain. His computed tomographic (CT) examination of the thorax showed pneumomediastinum. The patient was accepted as COVID-19 pneumonia and related pneumomediastinum. This case was presented to emphasize that patients with severe Covid-19 pneumonia on computed tomography may develop pneumomediastinum during treatment.
\end{abstract}

Keywords: SARS-COV-2, pneumomediastinum, COVID-19

\section{INTRODUCTION}

The new severe acute respiratory syndrome virus (SARS CoV-2) identified in the end of 2019 subsequently resulted in a global pandemic, as declared by the World Health Organization (WHO) in March 2020. ${ }^{[1]}$ SARS CoV-2 may not only lead to pneumonia and severe acute respiratory failure requiring ventilation, but it may also be associated with a number of other pulmonary and systemic complications. [2] Pneumonia is the most common lung manifestation of coronavirus disease 2019 (COVID-19). Pneumomediastinum (PM) is defined as the presence of free air between the mediastinal tissues due to intrathoracic and extrathoracic conditions. ${ }^{[3]}$ To our knowledge, there have been only limited case reports of SARS CoV-2 associated pneumomediastinum in the published literature.
Öz

COVID-19 pnömonisinde, spontan pnömomediastinum nadir gelişen bir komplikasyon olarak bildirilmiştir. Pnömomediastinumda semptomlar genellikle nonspesifiktir Otuz altı yaşında erkek hasta nefes darlığı, öksürük, sol yan ağrısı ile kliniğimize kabul edildi. Takiplerinde çekilen Bilgisayarlı toraks tomografisinde mediastende hava dansiteleri izlendi. Hasta COVID-19 pnömonisi ve buna bağlı gelişen pnömomediastinum olarak kabul edildi. Bu olgu bilgisayarlı tomografide ağır Covid-19 pnömonisi olan hastalarda tedavi sırasında pnömomediastinum gelişebileceğini vurgulamak amacıyla sunulmuştur.

Anahtar Kelimeler: SARS-COV-2, Pnömomediastinum, COVID-19

\section{CASE}

A 36-year-old male patient, who admitted to the emergency department with the complaints of cough, shortness of breath, and left flank pain for a week, was admitted to the chest diseases clinic with the diagnosis of pneumonia. His medical history was remarkable for chronic renal failure, hypertension and familial mediterranean fever (FMF), although he had no known pulmonary conditions. He was currently receiving colchicine for FMF, bisoprolol for hypertension. He was on hemodialysis 3 days of week. He had a 10 pack-year smoking history and was an ex smoker for 5 years. On admission, the patient was in moderate general condition, conscious, cooperative, oriented, blood pressure was 120/75 $\mathrm{mmHg}$, heart rate 74 beats per minute, respiratory rate 18 breaths/minute, and pulse oxygen 
saturation in room air was $99 \%$, body temperature was $37.6^{\circ} \mathrm{C}$. Respiratory system and other system examinations were normal. Laboratory data showed a CRP $24 \mathrm{mg} / \mathrm{L}$, procalcitonin $0.80 \mu \mathrm{g} / \mathrm{L}$, D-Dimer $75 \mathrm{ng} / \mathrm{mL}, \mathrm{LDH} 343 \mathrm{mg} / \mathrm{dL}$ (Table 1). Computed tomography of the thorax revealed ground glass and crazy paving accompanying peripheral consolidation areas containing air bronchograms in the left upper lobe of the lung (Figure 1). Since this appearance is not typical for COVID-19 pneumonia and the Polymerase Chain Reaction test was negative, the patient was started on nonspecific antibiotherapy (Moxifloxacin $400 \mathrm{mg} 1 \times 1$, piperacillintazobactam $3 \times 2.25 \mathrm{gr}$ ). On the $7^{\text {th }}$ day of treatment, the patient developed dyspnea. Oxygen saturation measured by pulse oximetry while breathing room air was $88 \%$. In biochemical parameters significant progression was detected (D-Dimer $992 \mathrm{ng} / \mathrm{mL}$, ferritin $1482 \mathrm{ng} / \mathrm{mL}$, LDH $504 \mathrm{mg} / \mathrm{dL}$, IL-6 10 pg/mL, Troponin 300 ng/L). Polymerase Chain Reaction test was negative. There was no growth in blood, urine, sputum, and catheter cultures. Galactomannan antigen and collagen tissue markers were negative (Table 1). In the control thorax tomography, widespread patchy-nodular multifocal ground glass opacities in both lungs, and interlobular septal thickening (crazy paving pattern) were observed. In addition, air densities were observed in the at the planes cervical level soft tissue and mediastinum. Findings were consistent with COVID-19 pneumonia and pneumomediastinum (Figure 2).

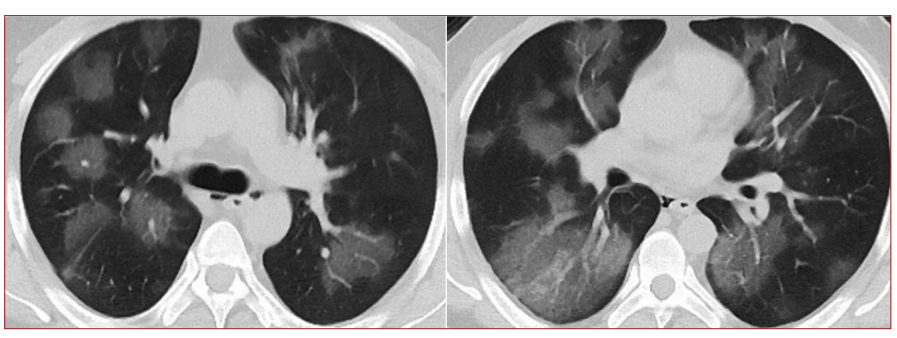

Figure 1. Thorax computerized tomography sections of the patient; ground glass and crazy paving accompanying peripheral consolidation areas containing air bronchograms in the left upper lobe of the lung.

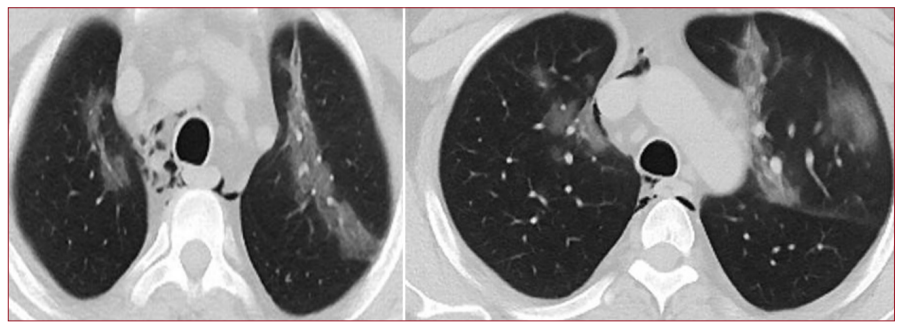

Figure 2. In the control thorax computerized tomography sections of the patient: widespread patchy-nodular multifocal ground glass opacities in both lungs, interlobular septal thickening, air densities in cervical level soft tissue and mediastinum.

The patient was considered to have COVID pneumonia and spontaneous pneumomedastinum due to increased dyspnea, hypoxemia, increase in inflammatory markers, progressive bilateral consolidation-ground glass opacities on $C T$, and the presence of pneumomediastinum during follow-up.
The patient, whose saturation was 88 in the absence of oxygen support, was followed up in the pulmonological intensive care unit. Treatments included immune plasma, antiviral treatment, pulsed steroid ( $250 \mathrm{mg} /$ day, 3 days, prednisolon) and nasal oxygen.

On the $20^{\text {th }}$ day of hospitalization, the symptoms completely resolved and the patient no longer needed oxygen. Significant improvement in laboratory parameters (Table 1), and radiological regression in bilateral ground glass infiltration and pneumomediastinum were observed. The patient was discharged with recommendations.

We present our case because spontaneous pneumomediastinum cases due to COVID-19 are rare in the literature.

\begin{tabular}{|c|c|c|c|c|}
\hline Variable & Admission & $7^{\text {th }}$ Day & Discharge & $\begin{array}{c}\text { Reference } \\
\text { Range }\end{array}$ \\
\hline D-Dimer & 675 & 992 & 916 & $0-500 \mathrm{ng} / \mathrm{ml}$ \\
\hline Fibrinogen & 700 & 700 & 253 & $200-400 \mathrm{mg} / \mathrm{dl}$ \\
\hline Ferritin & 260 & 1482 & 747 & $11-306 \mathrm{ng} / \mathrm{ml}$ \\
\hline $\mathrm{LDH}$ & 343 & 504 & 260 & $126-222 \mathrm{mg} / \mathrm{dl}$ \\
\hline IL-6 & & 10.6 & & $0.5-6.4 \mathrm{pg} / \mathrm{ml}$ \\
\hline CRP & 24 & 28 & 1.6 & $0-8 \mathrm{mg} / \mathrm{l}$ \\
\hline Procalcitonin & 0.83 & 6 & 0.15 & $0-0.5 \mathrm{ug} / \mathrm{l}$ \\
\hline Troponin & 10.6 & 300 & 17.5 & $0-17.5 \mathrm{ng} / \mathrm{l}$ \\
\hline PCR & Negative & Negative & Negative & Negative \\
\hline \multicolumn{2}{|c|}{ Galactomannan antigen } & Negative & & Negative \\
\hline Lactate & 1.2 & 4.9 & 2.2 & $0.3-2 \mathrm{mmol} / \mathrm{l}$ \\
\hline
\end{tabular}

\section{DISCUSSION}

Pneumomediastinum is a rare condition characterized by the presence of air in the mediastinum. ${ }^{[4]}$ Pneumomediastinum may occur in patients with COVID-19 pneumonia, either occurring spontaneously, or in association with invasive mechanical ventilation. ${ }^{[5,6]}$ Its pathophysiology involves the development of air dissection in the bronchovascular sheath due to a pressure gradient between the alveoliand interstitium, and was originally described by Maclin. ${ }^{[7]}$ Although the positive pressure in patients receiving non-invasive mechanical ventilation is of lesser degree as compared to invasive mechanical ventilation, pathophysiological mechanisms are probably similar. ${ }^{[8]}$

Symptoms and signs are generally non-specific, and include chest pain, dyspnea, dysphagia, cough, palpitations, agitation, sore throat, odynophagia, dysphonia, and hemoptysis. It may co-exist with subcutaneous emphysema and pneumothorax. Venous distention, hypotension, and reduced cardiac output may be observed in patients who also develop tension pneumomediastinum. ${ }^{[9]}$ Chest $\mathrm{x}$-ray is the initial examination of choice and allows a diagnosis to be established in most cases. Air collections around the esophagus, main bronchi, and mediastinum are highly suggestive of spontaneous Pneumomediastinum (SPM). ${ }^{[10]}$ 
PM is generally a self-limited condition that resorbs with prophylactic antibiotics and conservative treatment without prolonged hospitalization. However, evacuation of air with mediastinotomy may be required in tension pneumomediastinum..$^{[9]}$

Since COVID-19 related pulmonary infection infects both type I and type II pneumocytes, the integrity of the alveolar membrane is disrupted. ${ }^{[1]]}$ Therefore, injury to alveolar membrane may represent a possible mechanism leading to alveolar rupture and subsequent spontaneous pneumomediastinum.

Pneumothorax, pneumomediastinum, or subcutaneous emphysema have as been reported to occur due to mechanical ventilator-related barotrauma or ARDS in patients admitted to intensive care units. However, as a result of the lung-protective ventilation strategies adopted in the past two decades, a significant decline in the incidence of pneumomediastinum or subcutaneous emphysema due to barotrauma has been observed. On the other hand, a noticeable increase has been observed in the incidence of PM/ subcutaneous emphysema during the COVID-19 pandemic, despite continued use of such lung protective approaches. ${ }^{[12]}$ The patient reported herein developed SPM. A decrease in lung compliance, advanced age, and underlying lung disease (such as interstitial lung disease, chronic obstructive pulmonary disease cystic fibrosis, and certain lung infections like Pneumocystis jirovecii pneumonia) are known risk factors for non- trauma related pneumomediastinum. ${ }^{[13]}$ However, our patient had no such underlying conditions.

Pneumomediastinum has not been associated with increased mortality in COVID- 19 patients. ${ }^{[9]}$

Previously, a link between elevated LDH and increased risk of spontaneous pneumomediastinum has been proposed in patients infected with SARS. ${ }^{[14]}$ In this patient, the LDH level at presentation was $343 \mathrm{U} / \mathrm{L}$, rising dramatically to $504 \mathrm{U} / \mathrm{L}$ following admission to the intensive care unit. A possible link between elevated LDH due to cellular injury and development of PM, similar to that observed in SARS, cannot be excluded.

\section{CONCLUSION}

In this case report, a rare complication due to SARS CoV2 pneumonia has been described. In patients with severe CT signs of SARS CoV-2 pneumonia, it should be borne in mind that development of pneumomediastinum may be associated with poor prognosis. Further studies or case series are warranted to better elucidate the pathophysiological mechanisms.

\section{ETHICAL CONSIDERATIONS}

Informed Consent: Written informed consent was obtained from all participants who participated in this study.
Conflict of Interest Statement: The authors have no conflicts of interest to declare.

Financial Disclosure: The authors declared that this study has received no financial support.

Author Contributions: All of the authors declare that they have all participated in the design, execution, and analysis of the paper, and that they have approved the final version.

\section{REFERENCES}

1. Coronaviridae Study Group of the International Committee on Taxonomy of Viruses. The species Severe acute respiratory syndrome-related coronavirus: classifying 2019-nCoV and naming it SARS-CoV-2. Nat Microbiol. 2020;5(4):536-44.

2. Jain A, Talwar D, Kumar S. Spectrum of Respiratory Involvement in COVID 19 Era; An Overview. IJMTFM. 2020;14(4):6593-99.

3. Caceres M, Ali SZ, Braud R, Weiman D, Garrett HE Jr. Spontaneous pneumomediastinum: a comparative study and review of the literature. Ann Thorac Surg. 2008;86(3):962-6.

4. Goldman N, Ketheeswaran B, Wilson H. COVID-19-associated pneumomediastinum. Clin Med (Lond). 2020;20(4):91-2

5. Zhou C, Gao C, Xie Y, Xu M. COVID-19 with spontaneous pneumomediastinum. The Lancet Infectious Diseases. 2020;20(4):510.

6. Wali A, Rizzo V, Bille A, Routledge T, Chambers AJ. Pneumomediastinum following intubation in COVID-19 patients: a case series. Anaesthesia. 2020;75(8):1076-81.

7. Murayama S, Gibo S. Spontaneous pneumomediastinum and Macklin effect: Overview and appearance on computed tomography. World J Radiol. 2014;6(11):850-4.

8. Fukushima K, Marut K, Kiyofuji C, Sugimoto M. Evaluation of the incidence of pneumothorax and background of patients with pneumothorax during noninvasive positive pressure ventilation. Nihon Kokyuki Gakkai Zasshi. 2008;46(11):870-4.

9. Shennib HF, Barkun AN, Matouk E, Blundell PE. Surgical decompression of a tension pneumomediastinum. A ventilatory complication of status asthmaticus. Chest. 1988;93(6):1301-2.

10. Durukan P, Tekin I, Yakar S, Salt O, Baykan N, Ozkan S. Spontaneous pneumomediastinum: Case report. Gazi Med J 2017;28(4):275-7.

11. Gralinski LE, Baric RS. Molecular pathology of emerging coronavirus infections. J Pathol. 2015;235(2):185-95.

12. Lemmers DHL, Abu Hilal M, Bnà $C$, et all. Pneumomediastinum and subcutaneous emphysema in COVID-19: barotrauma or lung frailty? ERJ Open Res. 2020;6(4):00385-2020.

13. Kouritas VK, Papagiannopoulos K, Lazaridis G, et all. Pneumomediastinum. J Thorac Dis. 2015;7(Suppl 1):S44-9.

14. Chu CM, Leung YY, Hui JY, et all. Spontaneous pneumomediastinum in patients with severe acute respiratory syndrome. Eur Respir J. 2004;23(6):802-4. 